\title{
Bacterial profile and antimicrobial susceptibility pattern of asymptomatic urinary tract infections among pregnant women attending antenatal clinic at tertiary care hospital in central India
}

\author{
Pawar N. ${ }^{1}$, Sadawarte K. ${ }^{2 *}$, Prabhu K. T. ${ }^{3}$ \\ DOI: https://doi.org/10.17511/jopm.2019.i07.13 \\ 1 Namrata Pawar, Demonstrator, Department of Microbiology, Peoples College of Medical Sciences and Research center, Bhopal, Madhya \\ Pradesh, India. \\ 2* Kalpana Sadawarte, Professor, Department of Microbiology, Peoples College of Medical Sciences and Research center, Bhopal, Madhya \\ Pradesh, India. \\ 3 Tukaram Prabhu K., Assistant Professor, Department of Microbiology, Peoples College of Medical Sciences and Research center, Bhopal, \\ Madhya Pradesh, India.
}

Introduction: It is estimated that 2 to $10 \%$ of pregnant woman suffer from any form of urinary tract infections. These infections complicate up to $20 \%$ ofpregnancies and are responsible for the majority of ante-partum admissions to the maternal-fetal medicine units. Material and methods: It was a cross sectional study conducted in the Department of Microbiology, Peoples College of Medical Sciences \& Research Center, Bhopal (M.P) during period of July 2015 to March 2016. A total of 210 pregnant women having asymptomatic bacteriuria during the period of July2015 to March 2016 attending antenatal clinic were included (all trimester) in this study. Results: Women in age group 21-30years showed the highest incidence of asymptomatic bacteriuria (70.58\%), incidence of asymptomatic bacteriuria was generally high throughout pregnancy, but relatively highest during the second trimester. Escherichia coli was the most common 9 (52.94\%) followed by Staphylococcus aureus $4(23.52 \%)$, Klebisella pneumonia $2(11.76 \%)$ among the isolates. E.coli was found to be sensitive to cefepime and norfloxacin followed by ceftazidime ceftriaxone amoxicillin + clavulanic acid, nitrofurantoin, gentamycin and amikacin. Conclusion: This study revealed $8.09 \%$ prevalence of asymptomatic bacteriuria among pregnant women. This is of concern because UTI in pregnancy may have serious consequences for both the mother and the child.

Keywords: ANC, Asymptomatic bacteriuria, Pregnancy, UTI

Corresponding Author

Kalpana Sadawarte, Professor, Department of Microbiology, Peoples College of Medical Sciences and Research center, Bhopal, Madhya Pradesh, India. Email: drkalpanasadawarte@gmail.com

\section{How to Cite this Article}

Pawar N, Sadawarte K, Prabhu KT. Bacterial profile and antimicrobial susceptibility pattern of asymptomatic urinary tract infections among pregnant women attending antenatal clinic at tertiary care hospital in central India. Trop J Pathol Microbiol. 2019;5(7):500-504.

Available From

To Browse

https://pathology.medresearch.in/index.php/jopm/ar ticle/view/293
Manuscript Received 2019-07-10

Conflict of Interest No

Review Round 1
2019-07-20
Funding
Nil

Review Round 1

$\mathrm{Nil}$

Review Round 2
2019-07-26
Ethical Approval
Yes

(C) 2019 by Namrata Pawar, Kalpana Sadawarte Tukara Welfare Society. This is an Open Access articl Tukaram Prabhu K. and Published by Siddharth Health Research and Social https://creativecommons.org/licenses/by/4.0/ unported [CC BY 4.0].

Review Round 3

Plagiarism X-checker $5 \%$
Accepted 2019-07-30

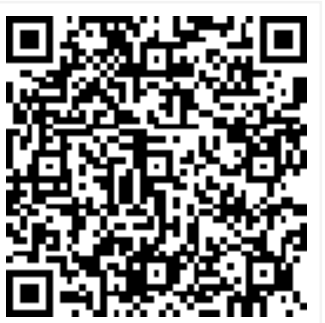




\section{Introduction}

It is estimated that several hundred million women suffer from urinary tract infection annually, with costs to health care providers amounting to over $\$ 6$ billion annually worldwide, a figure that may even be an underestimate [1].

It is estimated that 2 to $10 \%$ of pregnant woman suffer from any form of urinary tract infections [2]. These infections complicate up to $20 \%$ of pregnancies and are responsible for the majority of ante-partum admissions to the maternal-fetal medicine units [3].

Urinary tract infection (UTI) occurs frequently in pregnancy with a large number of infections being asymptomatic. The frequency of asymptomatic bacteriuria (ASB) in pregnancy accounts for the rationale of urinalysis throughout pregnancy period [4].

It can be associated with varieties of adverse obstetric outcome and medical conditions such as the development of acute and chronic pyelonephritis, preterm labour, low birth weight, pre eclampsia, chronic renal disease, and prenatal mortality [5]. Undiagnosed and untreated bacteriuria in pregnancy represents a considerable risk factor for acute pyelonephritis in approximately $5 \%$ of pregnant women with increased risk of low birth weight and prenatal fatal death [6].

Detection and treatment of bacteriuria has been reported to prevent up to $80 \%$ cases of pyelonephritis [7]. Bacteriuria in pregnancy usually reflects prior colonization e.g. at the time of onset of sexual activity rather than acquisition during pregnancy itself [8]. Furthermore, there is obviously a substantial risk that the infecting pathogens are becoming resistant to empirically prescribed antimicrobial agents normally used in the community.

\section{Material and methods}

Study design: It was a Cross sectional study

Study place: The study was conducted in the department of Microbiology, Peoples College of Medical Sciences \& Research Center, Bhopal (M.P).

Study duration: July 2015 to March 2016.

Sample size: A total number of 210 pregnant women attended antenatal clinic and had asymptomatic bacteriuria during the period of July
2015 to March 2016 were included (all trimester) in this study.

Inclusion criteria: Pregnant women who had asymptomatic bacteriuria were included.

Exclusion criteria: Diabetes mellitus/hypertension, fever and known congenital anomalies of urinary tract will be excluded from this study.

Sample collection: About $30 \mathrm{ml}$ of clean catch midstream urine sample was collected in $100 \mathrm{ml}$ sterile, dry, leak-proof container [9]. The patients were instructed to discard first $10-30 \mathrm{ml}$ of the voided urine and collect about $30 \mathrm{ml}$ of the second midstream urine. The pregnant woman was instructed to adequately clean the peri-urethral area with water and soap solution without antibacterial activity [10].

Transport: Urine specimen was transported to the laboratory immediately after obtaining and was processed within one hour or in case of delay they were refrigerated at $4^{\circ} \mathrm{C}$ (upto 24 hours), until culture could be performed [11].

Microscopic examination: At first, urine was examined microscopically as a wet preparation to detect

Significant pyuria, Urine is mixed carefully and $0.05 \mathrm{ml}$ is transferred on to the middle of a microscope slide and applies cover slip. The preparation was examined microscopically using the $10 x$ and $40 x$ to look for bacteria, pus cells, epithelial cells, crystals.

Semi quantitative Urine culture was done using calibrated wire loop $(0.005 \mathrm{ml})$ of 28 SWG which had internal diameter of $3.28 \mathrm{~mm}$ [12], and urine samples were inoculated into Cystine Lactose Electrolyte Deficient medium. Culture plate was incubated in aerobic atmosphere at $37^{\circ} \mathrm{C}$ for $18-24$ hours [13]. Colonies were counted to check the presence of significant bacteriuria Colony count yielding bacterial growth of $105 \mathrm{CFU} / \mathrm{ml}$ of urine was regarded as significant bacteriuria. If the colony forming unit (CFU) is less than 105, it was considered as non significant bacteriuria or negative [14].

All positive cultures with significant bacteriuria were then identified to species level by their colony characteristics, gram staining reaction and by the pattern of biochemical profiles using standard procedures. 
Positive control: Staphylococcus aureus ATCC 25923.

Negative control: Escherichia coli ATCC 25922.

Biochemical reactions: Following biochemical test were put up to identify bacteria to species level such as catalase, coagulase for gram positive and oxidase, indole, citrate, urea, triple sugar iron, lysine decarboxylase, arginine and ornithine and motility testfor Gram negative bacteria following standard procedure.

\section{Results}

Out of 210 urine samples of ANC Women examined for asymptomatic bacteriuria, 17 were having significant bacteriuria $(105 \mathrm{cfu} / \mathrm{ml})$ giving frequency rate of $8.09 \%$.

The frequency of asymptomatic bacteriuria according to age distribution showed that majority of the subjects screened were in the age group of 21-30 years, Women in age group 21-30 years showed the highest incidence of asymptomatic bacteriuria (70.58\%) is shown in Table 1.

Table No.-1: Frequency of ASB in relation to age distribution of pregnant women

\begin{tabular}{|l|l|l|l|}
\hline Age distribution & No. of samples & No. Positive & Percentage \\
\hline$\leq 20$ & 26 & 2 & $(11.79)$ \\
\hline $21-30$ & 129 & 12 & $(70.58)$ \\
\hline $31-\geq 40$ & 55 & 3 & $(17.64)$ \\
\hline Total & 210 & 17 & 100 \\
\hline
\end{tabular}

Frequency of asymptomatic bacteriuria was generally high among the three trimesters, but relatively highest during the second trimester as shown in Table 2.

Table No.-2: Incidence of ASB by trimester.

\begin{tabular}{|l|l|l|l|}
\hline \multicolumn{1}{|c|}{ Trimester } & No. tested & Positive & \multicolumn{1}{c|}{ Percentage } \\
\hline 1st & 42 & 3 & 17.64 \\
\hline 2nd & 91 & 9 & 52.94 \\
\hline 3rd & 77 & 5 & 29.41 \\
\hline Total & 210 & 17 & 100 \\
\hline
\end{tabular}

Our study showed that Escherichia coli was the most common - 9 (52.94\%) followed by Staphylococcus aureus 4(23.52\%), Klebsiella pneumonia 2 (11.76\%) among the isolates as shown in Table 3.

Table No.-3: Isolates obtained using standard biochemical tests

\begin{tabular}{|l|l|l|}
\hline \multicolumn{1}{|c|}{ Isolates } & \multicolumn{1}{|c|}{ Number $(\mathbf{n = 2 1 0})$} & \multicolumn{1}{c|}{ Percentage } \\
\hline Escherichia coli & 9 & $(52.94)$ \\
\hline Staphylococcus aureus & 4 & $(23.52)$ \\
\hline Klebishella pneumonia & 2 & $(11.76)$ \\
\hline Proteus mirabilis & 1 & $(5.88)$ \\
\hline Pseudomonas aeroginosa & 1 & $(5.88)$ \\
\hline Total & 17 & $17(8.09)$ \\
\hline
\end{tabular}

In our study, E.coli was found to be sensitive to cefepime and norfloxacin followed by ceftazidine ceftriaxone amoxicillin + clavulanic acid, nitrofurantoin Gentamycin and amikacin as shown in table no. 4.

Table No.-4: Antimicrobial susceptibility pattern of bacteria isolates.

\begin{tabular}{|c|c|c|c|c|c|c|c|c|c|c|}
\hline \multirow[t]{2}{*}{ Antibiotics } & \multicolumn{2}{|c|}{ E. Coli $(n=9)$} & \multicolumn{2}{|c|}{ K. pneumoniae ( $n=2)$} & \multicolumn{2}{|c|}{ Proteus $(\mathrm{n}=\mathbf{1})$} & \multicolumn{2}{|c|}{ Pseudomonas ( $n=1)$} & \multicolumn{2}{|c|}{ Staphylococcus ( $n=4)$} \\
\hline & $S$ & $R$ & $s$ & $R$ & $s$ & $R$ & $s$ & $R$ & $s$ & $R$ \\
\hline Ampicillin & 5 & 4 & 1 & 1 & 1 & 0 & 0 & 1 & 2 & 2 \\
\hline Amikacin & 6 & 3 & 1 & 1 & 1 & 0 & 1 & 0 & 2 & 2 \\
\hline Amoxycillin+ clavulanic acid & 7 & 2 & 1 & 1 & 1 & 0 & 0 & 1 & 3 & 1 \\
\hline Gentamycin & 6 & 3 & 2 & 0 & 0 & 1 & 1 & 0 & 2 & 2 \\
\hline Cefepime & 8 & 1 & 0 & 2 & 1 & 0 & 1 & 0 & - & - \\
\hline Ceftazidime & 7 & 2 & 2 & 0 & 1 & 0 & 1 & 0 & - & - \\
\hline Ceftriaxone & 7 & 2 & 1 & 1 & 1 & 0 & 1 & 0 & - & - \\
\hline Norfloxacin & 8 & 1 & 1 & 1 & 1 & 0 & 0 & 1 & 4 & 0 \\
\hline Nitrofurantoin & 6 & 3 & 1 & 1 & 0 & 1 & 0 & 1 & 2 & 2 \\
\hline Cotrimoxazole & 4 & 6 & 1 & 1 & 0 & 1 & 0 & 1 & 1 & 3 \\
\hline Cefoxitin & - & - & - & - & - & - & - & - & 2 & 2 \\
\hline Ampicillin + Sulbactum & - & - & - & - & - & - & - & - & 3 & 1 \\
\hline
\end{tabular}

*(The isolate in which antibiotic sensitivity was not performed is shown by -) 


\section{Discussion}

In the present study, the frequency of asymptomatic bacteriuria was $8.09 \%$ (17 cases) among the sampled population of 210 pregnant women attending ante-natal clinic. Similar observations were found by other authors [15] although R Sujata et al found it to be $3 \%$ which is less than our study [16]. This variation may be explained by the differences in the environment, social habits ofthe community, the standard of personal hygiene and education. In the present study, the subjects in the age groups of 21-30 years showed the highest frequency of infection (70.58\%). Study conducted by Lavanya et al [17] reported higher frequency in subjects belong to the age group of 25-30 years, although R Sujata et al [16] found that the age group of 21-30 yrs had higher frequency of infection $(72.72 \%)$. In other study conducted by Kasinathan A et al [18] subjects belong to the age group of 2630 years had maximum frequency of infection $(59.1 \%)$ which is lower than the present study.

Among positive cultures which were obtained $17.64 \%$ belonged to primigravidae and $29.41 \%$ belonged to multigravidae in contrast to study by $R$. Sujata et al. which showed $48.9 \%$ in primigravidae and $51.1 \%$ belonging to multigravidae [16]. There was no difference in frequency of urinary tract infection in pregnant women with previous history of urinary tract infection and those without.

In the present study, it was observed that the women in their second and third trimester had higher frequency of asymptomatic bacteriuria $(52.94 \%)$, and this could be attributed to the anatomical and physiological changes experienced by pregnant women during these stage of pregnancy, for instance the uterus expands and also there are increased hormonal effects which together offset normal homeostatic balance making conditions favorable for microbial invasion.

Though frequency of UTI in the first trimester was low it could only be that it served as incubation period for most of the microbes, only for microbial invasion to be manifest in the second and third trimester [19].

In the present study it was observed that Escherichia coli was the most common isolated organism in 9 (52.94\%) subjects followed by Staphylococcus aureus 4 (23.52\%), Klebsiella pneumonia $2(11.76 \%)$ among the isolates.
There were one isolate of Proteus mirabilus and Pseudomonas aeroginosa each. Other studies have also reported that Escherichia coli were often the most common isolated organism in asymptomatic bacteriuria [20-22].

In the present study, E.coli was found to be sensitive to cefepime and norfloxacin followed by ceftazidine, ceftriaxone amoxicillin + clavulanic acid, nitrofurantoin Gentamycin and amikacin. This was in accordance to the study done by Andabati $G$ and Byamugisha et al in Africa in 2010 [23].

\section{Conclusion}

High prevalence of asymptomatic bacteriuria among pregnant women is of concern because UTI in pregnancy may have serious consequences for both the mother and the child. The most predominant organisms were Escherichia coli and Staphylococcus aureus. Nor-floxacin, Ceftriaxone, Cefepime and Amoxycillin + clavulanic acid were very effective against most of the urinary isolates.

\section{What the study adds in the existing knowledge?}

Routine urine culture test should be carried out on all antenatal women to detect asymptomatic bacteriuria. Screening should be done regularly for the presence of asymptomatic bacteriuria in pregnancy and testing antimicrobial susceptibility with safe drugs in pregnant women is also necessary, so that these can be used for the treatment.

\section{Author's contribution}

Dr. Namrata Pawar: Experimental work. Dr. Kalpana Sadawarte: Review of literature, Statistical Analysis. Mr. Tukaram Prabhu K: Preparation of manuscript.

\section{Reference}

01. Aviva R Eric, LY David W. Urinary Complaints- In Botanical Medicine for Women's Health. Published by Churchill Livingstone. 2010;290-305. [Crossref] [PubMed][Google Scholar]

02. Lee M, O'Brien P. Pregnancy and multiple sclerosis. J Neurol Neurosurg Psychiatry. 2008;79(12)1308-1311. doi: 10.1136/jnnp.2007.116947 [Crossref][PubMed] [Google Scholar] 
03. Sheffield JS, Cunningham FG. Urinary tract infection in women. Obstet Gynecol. 2005;106(5 Pt 1)1085-1092.

doi:10.1097/01.AOG.0000185257.52328.a2

[Crossref][PubMed][Google Scholar]

04. Stamm WE, Hooton TM. Management of urinary tract infections in adults. N Engl J Med. 1993;329(18)1328-1334. doi: 10.1056/NEJM199 310283291808 [Crossref][PubMed][Google Scholar]

05. Najar MS, Saldanha CL, Banday KA. Approach to urinary tract infections. Indian J Nephrol. 2009;19(4)129-139. doi: 10.4103/09714065.59333 [Crossref][PubMed][Google Scholar]

06. Hazhir S. Asymptomatic bacteriuria in pregnant women. Urol J. 2007 Winter;4(1)24-7. [Crossref] [PubMed][Google Scholar]

07. Schnarr J, Smaill F. Asymptomatic bacteriuria and symptomatic urinary tract infections in pregnancy. Eur J Clin Invest. 2008;38(2)50-57. doi:10.1111/j.1365-2362.2008.02009.x [Crossref] [PubMed][Google Scholar]

08. Smaill FM, Vazquez JC. Antibiotics for asymptomatic bacteriuria in pregnancy. Cochrane Database Syst Rev. 2015(8)CD000490. doi: 10.1002/1465185 8.CD000490.pub3 [Crossref][PubMed][Google Scholar]

09. Petri W A. Penicillins, cephalosporins, and other $\beta$-Lactam antibiotics, In- Goodman and Gilman's and Gilman's the pharmaclological Basis of Therauptics. The McGraw Hill Companies. 2006; (11)1127, 1150-1152. [Crossref][PubMed][Google Scholar]

10. Samaha-Kfoury JN, Araj GF. Recent developments in beta lactamases and extended spectrum beta lactamases. BMJ. 2003;327 (7425)1209-13. doi: 10.1136/bmj.327.7425.1209 [Crossref][PubMed][Google Scholar]

11. Turck M, Goffe BS, Petersdorf RG. Bacteriuria of pregnancy- Relation to socioeconomic factors. New Eng J Med. 1962:266;857-60. doi: 10.1056/NEJM19 $6204262661703 \quad$ [Crossref][PubMed][Google Scholar]

12. Sawai T, Mitsuhashi S, Yamagishi S. Drug Resistance of Enteric Bacteria- XIV, Comparison of $\beta$-Lactamases in Gram-negative Rod Bacteria Resistant to a-Aminobenzylpenicillin. Jap J Microbiol. 1968;12(4)423-34. doi: 10.1111/j.1348-0421.196 8.tb00415.x [Crossref][PubMed][Google Scholar]
13. Kapil A. Enterobacteriacea- I coliforms-Proteus, In Ananthanarayan and Paniker's. Text book of Microbiology 9th ed Hyderabad- University press. 2013;275-284. [Crossref][PubMed][Google Scholar]

14. Bradford PA. Extended-spectrum betalactamases in the 21st century- characterization, epidemiology, and detection of this important resistance threat. Clin Microbiol Rev. 2001;14(4)933-951. doi: 10.1128/CMR.14.4.933951.2001 [Crossref][PubMed][Google Scholar]

15. Nithyalaxami J Vijayalaxami. Bacterial profile and antibiogram pattern of UTI in pregnant women. Int J Pharm Bio Sci. 2014;5(4)201-207. [Crossref] [PubMed][Google Scholar]

16. Sujatha $R$, Nawani $M$. Prevalence of asymptomatic bacteriuria and its antibacterial susceptibility pattern among pregnant women attending the antenatal clinic at Kanpur, India. Journal of clinical and diagnostic research- JCDR. 2014;8(4)DC01.

doi: 10.7860/JCDR/2014/6599.4205 [Crossref][PubMed] [Google Scholar]

17. Lavanya SV, Jogalakshmi D. Asymptomatic bacteriuria in antenatal women. Indian J Med Microbiol. 2002;20(2)105-6. [Crossref][PubMed] [Google Scholar]

18. Kasinathan A, Thirumal P. Prevalence of asymptomatic bacteriuria in antenatal women attending a tertiary care hospital. Int J Reprod Contracept Obstet Gynecol. 2014;3(2)437-1. doi: 10.5455/2320-1770.Ijrcog 20140631 [Crossref] [PubMed][Google Scholar]

19. Prakash D, Saxena RS. Distribution and antimicrobial susceptibility pattern of bacterial pathogens causing urinary tract infection in urban community of meerut city, India. ISRN Microbiol. 2013;29;749629. doi: 10.1155/2013/749629 [Crossref][PubMed][Google Scholar]

20. Jolley JA, Wing DA. Pyelonephritis in pregnancy: an update on treatment options for optimal outcomes. Drugs. 2010;10;70(13)1643-55. doi: 10.2165/11538050-000000000-00000 [Crossref] [PubMed][Google Scholar]

21. Turck M, Goffe BS, Petersdorf RG. Bacteriuria of pregnancy, Relation to socioeconomic factors. N Engl J Med. 1962 26;266;857-60. doi:10.1056/NEJM 196204262661703 [Crossref] [PubMed][Google Scholar] 
22. Boye A, Siakwa PM, Boampong JN, Koffuor GA, Ephraim RK, Amoateng $\mathrm{P}$, et al. Asymptomatic Urinary Tract Infection in Pregnant Women. E3 J Med Res. 2012;1(6)74-83. [Crossref][PubMed] [Google Scholar]
23. Andabati G, Byamugisha J. Microbial aetiology and sensitivity of asymptomatic bacteriuria among ante-natal mothers in Mulago hospital, Uganda. African Health Sci. 2010;10(4)349-352. [Crossref] [PubMed][Google Scholar] 